\title{
Recent Progress in Green Cement Technology Utilizing Low-Carbon Emission Fuels and Raw Materials: A Review
}

\author{
Ali Naqi and Jeong Gook Jang * \\ Division of Architecture and Urban Design, Institute of Urban Science, Incheon National University, \\ 119 Academy-ro, Yeonsu-gu, Incheon 22012, Korea; aliravian@inu.ac.kr \\ * Correspondence: jangjg@inu.ac.kr; Tel.: +82-(0)32-835-8472
}

Received: 6 December 2018; Accepted: 15 January 2019; Published: 21 January 2019

check for updates

\begin{abstract}
The cement industry is facing numerous challenges in the 21st century due to depleting natural fuel resources, shortage of raw materials, exponentially increasing cement demand and climate linked environmental concerns. Every tonne of ordinary Portland cement (OPC) produced releases an equivalent amount of carbon dioxide to the atmosphere. In this regard, cement manufactured from locally available minerals and industrial wastes that can be blended with OPC as substitute, or full replacement with novel clinkers to reduce the energy requirements is strongly desirable. Reduction in energy consumption and carbon emissions during cement manufacturing can be achieved by introducing alternative cements. The potential of alternative cements as a replacement of conventional OPC can only be fully realized through detailed investigation of binder properties with modern technologies. Seven prominent alternative cement types are considered in this study and their current position compared to OPC has been discussed. The study provides a comprehensive analysis of options for future cements, and an up-to-date summary of the different alternative fuels and binders that can be used in cement production to mitigate carbon dioxide emissions. In addition, the practicalities and benefits of producing the low-cost materials to meet the increasing cement demand are discussed.
\end{abstract}

Keywords: green cement; alternative binders; cement industry; $\mathrm{CO}_{2}$ emission; alternative fuel

\section{Introduction}

Concrete and its dominated precursor, cement, have ruled the construction industry for the past 150 years with manufacturing rate rising from 1500 million tonnes in 2000 to over 3 billion tonnes in 2012 [1]. Ordinary Portland cement (OPC) has established itself a vital and strategic commodity material [2] and such is our dependence on OPC that the annual global cement production has now reached up to 4 billion tonnes due to the rapid infrastructural growth of developing economies [3]. It is estimated that around $50 \%$ of world's OPC is consumed to make nearly 11 billion tonnes of concrete per year, while rest is used for mortars, stucco, screeds, coatings, and other applications [4]. With increasing infrastructure and building demands in near future, a sustainable, durable, and economical concrete is increasingly desirable [5]. The demand for concrete is anticipated to increase over 18 billion tonnes per annum by 2050 [6]. In recent years, Northern Africa, Middle East regions, and developing countries like China and India have seen major growth. Today, China is dominating the cement market by producing $58.13 \%$ of the world total consumption [3]. With an estimation of over 3.5 billion tonnes of cement produced annually, approximately $900 \mathrm{~kg}$ of $\mathrm{CO}_{2}$ is released per one tonne of cement produced [7]. This estimation equates over 3 billion tonnes of $\mathrm{CO}_{2}$ per year. Thus, cement industry is responsible for approximately $5-7 \%$ of total $\mathrm{CO}_{2}$ emissions [8]. Not only $\mathrm{CO}_{2}$ releases from cement plants, but also $\mathrm{SO}_{2}$ (sulfur dioxide), $\mathrm{NO}_{\mathbf{x}}$ (nitrous oxides) contribute to greenhouse effect and acid rain [9]. Apart from these gas emissions, cement production 
contributes to the consumption of significant quantities of natural resources. It was reported that to manufacture one tonne of OPC approximately required 1.5 tonnes of raw materials [10,11]. Furthermore, clinker manufacturing involves massive energy [12]. Therefore, cement industry is facing tremendous challenges such as depleting natural resources, increasing costs of energy supplies, $\mathrm{CO}_{2}$ emission reduction requirements, and ensuring the proper supply of raw materials with the current increasing demand $[13,14]$.

Consequently, there is a need to seek an alternative to partially/fully replace cement with environmentally friendly cementitious composite to reduce the adverse environmental impact of concrete production. One effective alternative to mitigate air pollution is utilization of by-products (fly ash, slag, silica fume, recycled products, and other waste materials) as partial replacement of cement [15-18]. The other alternative is replacement of conventional cement with new resource efficient cements that will emit less $\mathrm{CO}_{2}$ and consume less energy without compromising the efficiency and quality of binder [19-22]. The environmental performances of raw materials substitution are defined by a SUB-RAW index, based on consumed energies and carbon emissions in the formation of material. SUB-RAW index represents a simplified quantitative approach to evaluate the environmental sustainability of materials substitution [23,24]. This method is applied to a real case of coal fly ash (CFA), which partially substitute for Portland cement [24]. The present study covers a wide range of alternative approaches to mitigate $\mathrm{CO}_{2}$ emissions linked to the production of binder phase. These ranges from replacing the conventional raw materials and fuels used for Portland cements production to complete replacement of cement clinker with novel clinker such as sulfoaluminate cements and magnesia cements. Not only the basic chemical properties, but the microstructure and manufacturing of alternative binders, engineering performances, and environmental aspects compared to OPC are discussed in detail.

\section{Current Status of Portland Cements}

\subsection{Manufacturing Process}

Portland cement is a vital and dominated construction material in the world. It is a mixture of about $80 \%$ burning limestone and $20 \%$ clay. Cement clinker is manufactured by calcining limestone (calcium source), clay, or sand (silica and alumina source) in a rotary kiln at temperature of about $1450{ }^{\circ} \mathrm{C}$ [2]. The raw materials such as limestone and chalk for calcium and clay for silica are easily available. The grinding of clinker combined with around 5\% of gypsum (calcium sulphate) forms Portland cement. Approximately $50 \%$ emissions of $\mathrm{CO}_{2}$ are directly emitted from the calcination process (decarbonation of limestone), $40 \%$ from fuel combustion in rotary kiln, and $10 \%$ are indirect emissions accounted for quarrying and transportation of products [25]. Calcination is the decomposition of calcium carbonate (lime stone) to calcium oxide $(\mathrm{CaO})$ and $\mathrm{CO}_{2}$. In the cement industry, the product of calcination is called clinker. Calcination process occurs when calcium carbonate $\left(\mathrm{CaCO}_{3}\right)$ and silicon dioxide $\mathrm{SiO}_{2}$ are combined in furnace at $1450{ }^{\circ} \mathrm{C}$, which results in the formation of the following products, i.e., alite (tricalcium silicate) [1].

$$
\begin{array}{lll}
3 \mathrm{CaCO}_{3}+\mathrm{SiO}_{2} \stackrel{\text { heat }}{\rightarrow} \mathrm{Ca}_{3} \mathrm{SiO}_{5}+3 \mathrm{CO}_{2} \\
\text { calcium silica } & \begin{array}{l}
\text { calcium } \\
\text { silicate }
\end{array} & \text { dioxon } \\
\text { carbonate } & \text { (clinker) }
\end{array}
$$

The grinding of clinker to fine powder that produces Portland cement will react with water to form a solid mass. Table 1 shows main constituents of Portland cement and their typical percentages by weight. The compounds are formed because of pyroprocessing from limestone and clay. Portland cements are classified as a type of the calcium silicate hydrate hydraulic cements. Most hydraulic cements are composed of calcium compounds that easily get hydrated [26]. In the hydration process, cement compounds undergo chemical reaction with water to form a stable solid hydrate. Although cement paste occupies only $10-15 \%$ of mass in concrete, this minor portion has a significant role to determine the fresh and hardened properties of concrete [27]. 
Table 1. Main constituents of Portland cement and their percentages by weight [1].

\begin{tabular}{ccc}
\hline Tricalcium silicate, alite & $50 \%$ & $\mathrm{Ca}_{3} \mathrm{SiO}_{5}$ or $3 \mathrm{CaO} . \mathrm{SiO}_{2}$ \\
Dicalcium silicate, belite & $25 \%$ & $\mathrm{Ca}_{2} \mathrm{SiO}_{4}$ or $2 \mathrm{CaO} \cdot \mathrm{SiO}_{2}$ \\
Tricalcium aluminate, aluminate & $10 \%$ & $\mathrm{Ca}_{3} \mathrm{Al}_{2} \mathrm{O}_{6}$ or $3 \mathrm{CaO} \cdot \mathrm{Al}_{2} \mathrm{O}_{3}$ \\
Tetracalcium aluminoferrite, ferrite & $10 \%$ & $\mathrm{Ca}_{4} \mathrm{Al}_{2} \mathrm{Fe}_{2} \mathrm{O}_{10}$ or $4 \mathrm{CaO} \cdot \mathrm{Al}_{2} \mathrm{O}_{3} \cdot \mathrm{Fe}_{2} \mathrm{O}_{3}$ \\
Gypsum & $5 \%$ & $\mathrm{CaSO}_{4} \cdot 2 \mathrm{H}_{2} \mathrm{O}$ \\
\hline
\end{tabular}

Portland cement is rich in alite and belite phases with some amounts of aluminate and ferrite. Upon hydration both alite and belite phases combine to form calcium silicate hydrate (C-S-H), the colloidal gel that cohesively join the cement particles and calcium hydroxide $(\mathrm{CH})$ together. The solid mass consists of $50-60 \%$ C-S-H, 20-25\% CH, and 15-20\% calcium sulfoaluminate hydrates. Hereafter, cement chemistry symbols are denoted as: $\mathrm{C}=\mathrm{CaO}, \mathrm{S}=\mathrm{SiO}_{2}, \mathrm{~A}=\mathrm{Al}_{2} \mathrm{O}_{3}, \mathrm{~F}=\mathrm{Fe}_{2} \mathrm{O}_{3}, \overline{\mathrm{S}}=\mathrm{SO}_{3}$.

\subsection{Global Production and Environmental Impacts}

The production of cement differs from country to country greatly depends upon availability of raw materials. Countries which do not produce sufficient cement to fulfil its country needs have to import it from other countries to meet its needs. A recent survey showed global production of cement exceeded 4 billion tonnes where China dominated the most of the market, as shown in Figure 1 [3], while a typical cement plant generation capacity remains in range of 1.5-2.5 million tonnes annually [28]. In the recent decade, the cement production rate has been drastically increased and the industry has been growing especially in developing countries in Asia like China and India.

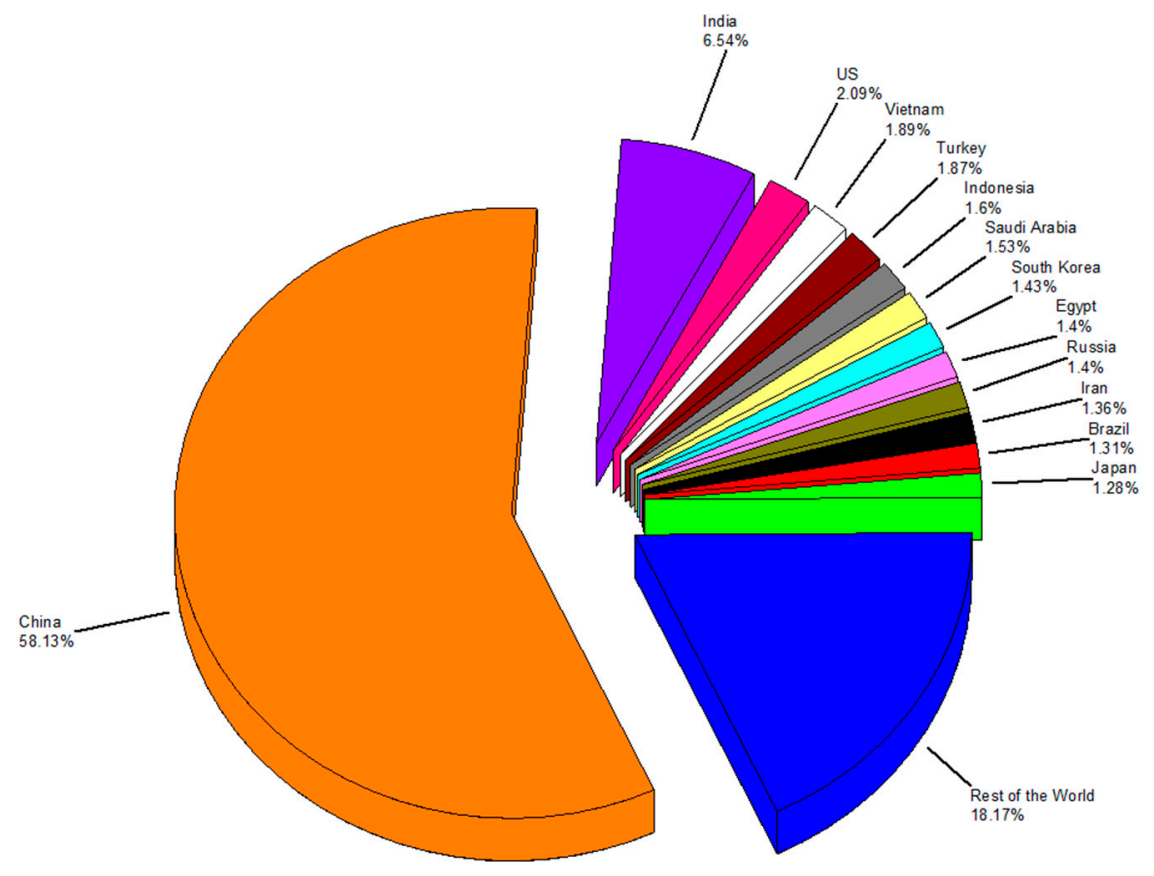

Figure 1. Global cement production in 2017. Data adopted from [3].

The major environmental impacts related with cement include energy required for manufacturing, direct and indirect greenhouse gases emission during production and transportation of clinker, mining of natural resources, and waste generation. Many detailed environmental studies have been conducted on the impacts of different major processes involved in cement production [29-32]. The main sources of the gas emissions in Portland cement manufacturing are divided into two parts:

(1) Calcination process that is responsible for around $50 \%$ of the total emissions;

(2) Fuel combustion used to heat raw materials. 
Environmental issues range from local scale, cement kiln dust (CKD), to global scale (such as $\mathrm{CO}_{2}-\mathrm{SO}_{2}-\mathrm{NO}_{\mathrm{x}}$ emissions). CKD size smaller than $10 \mu \mathrm{m}$ are classified as PM10. A summary of different gasses emission during the cement production process is presented in Table 2.

Table 2. Summary of gases emission during cement manufacturing processes expressed in $\mathrm{g} / \mathrm{kg}$ * cement and $\mathrm{g} / \mathrm{kg}$ ** clinker.

\begin{tabular}{|c|c|c|c|c|c|c|c|c|}
\hline \multirow{2}{*}{$\begin{array}{c}\text { Ref. } \\
{[33]}\end{array}$} & \multicolumn{2}{|c|}{$\mathrm{CO}_{2}$} & \multicolumn{2}{|c|}{$\mathrm{SO}_{2}$} & \multicolumn{2}{|c|}{$\mathrm{NO}_{\mathrm{x}}$} & \multicolumn{2}{|c|}{ CKD/PM-10 } \\
\hline & 870 & $\mathrm{~g} / \mathrm{kg}$ * & - & - & - & - & - & - \\
\hline [34] & 810 & $\mathrm{~g} / \mathrm{kg}$ * & - & - & - & - & - & - \\
\hline [35] & 800 & $\mathrm{~g} / \mathrm{kg}$ * & $0.40-0.60$ & $\mathrm{~g} / \mathrm{kg}$ * & 2.4 & $\mathrm{~g} / \mathrm{kg}$ * & $0.1-10$ & $\mathrm{~g} / \mathrm{kg}^{*}$ \\
\hline [36] & 820 & $\mathrm{~g} / \mathrm{kg}$ * & - & - & - & - & - & - \\
\hline [37] & 690 & $\mathrm{~g} / \mathrm{kg}$ * & 0.82 & $\mathrm{~g} / \mathrm{kg} *$ & 1.2 & $\mathrm{~g} / \mathrm{kg}$ * & 0.49 & $\mathrm{~g} / \mathrm{kg} *$ \\
\hline [38] & 810 & $\mathrm{~g} / \mathrm{kg}$ * & 0.58 & $\mathrm{~g} / \mathrm{kg}$ * & 1.5 & $\mathrm{~g} / \mathrm{kg}$ * & 0.04 & $\mathrm{~g} / \mathrm{kg}$ * \\
\hline [39] & 900 & $\mathrm{~g} / \mathrm{kg}$ * & 0.27 & $\mathrm{~g} / \mathrm{kg}^{* *}$ & $1-4$ & $\mathrm{~g} / \mathrm{kg}^{* *}$ & 200 & $\mathrm{~g} / \mathrm{kg}$ ** \\
\hline [40] & 895 & $\mathrm{~g} / \mathrm{kg}$ * & - & - & - & - & $150-200$ & $\mathrm{~g} / \mathrm{kg}^{* *}$ \\
\hline [41] & - & - & 0.54 & $\mathrm{~g} / \mathrm{kg} * *$ & - & - & - & - \\
\hline [42] & - & - & - & - & 2.5 & $\mathrm{~g} / \mathrm{kg}$ ** & $0.1-0.3$ & $\mathrm{~g} / \mathrm{kg} * *$ \\
\hline Mean & 814 & $\mathrm{~g} / \mathrm{kg}$ * & 0.5 & $\mathrm{~g} / \mathrm{kg}$ * & 2.5 & $\mathrm{~g} / \mathrm{kg}$ * & 25 & $\mathrm{~g} / \mathrm{kg}$ * \\
\hline
\end{tabular}

Gartner [40] distinguished $\mathrm{CO}_{2}$ emissions during calcination (raw material $\mathrm{CO}_{2}$ ) and energy associated emissions (energy bound $\mathrm{CO}_{2}$ ). Regarding energy bound emissions, an efficiency of rotary kiln plays a key role. Table 3 shows specific thermal consumption in cement clinker process, which is linked to the technology used. Using suitable kiln type can reduce energy consumption to less than $2.9 \mathrm{GJ} /$ ton clinker, while a typical cement kiln consumes $3.1 \mathrm{GJ} /$ ton of energy with a carbon emission of approximately $0.31 \mathrm{~kg}[43]$.

Table 3. Specific thermal energy consumption in a clinker manufacturing process [43].

\begin{tabular}{cc}
\hline Kiln Process & Thermal Energy Consumption (GJ/Clinker) \\
\hline Wet process & $5.85-6.28$ \\
Long dry process & 4.60 \\
Shaft kiln & $3.70-6.60$ \\
1-stage cyclone preheater & 4.18 \\
2-stage cyclone preheater & 3.77 \\
4-stage cyclone preheater & 3.55 \\
4-stage cyclone preheater plus calciner & 3.14 \\
6-stage cyclone preheater plus calciner & $<2.93$ \\
\hline
\end{tabular}

Raw-material-based emissions are limited. Partial replacement of raw materials with supplementary cementitious materials, such as blast furnace slag or fly ash is one option. Replacement levels up to $10 \%$ are commonly reported [44]. For 10\%, limestone replacement, in theory, carbon dioxide emissions can be reduced up to $25 \%$ [43].

\section{Resource Efficient Cements}

\subsection{Alternative Fuel}

The term alternative fuels refers to waste materials used for the clinker production in cement industry, which is undoubtedly of great importance for not only the manufacturers but also for society. Traditionally, firing of clinker is done with either local fuel, natural gas, or fuel oil. The trend of utilizing alternative fuel sources started in the mid-1980s. Fuels like bio mass can effectively reduce the $\mathrm{CO}_{2}$ emissions by $20-25 \%$ compared to those of coal [44]. The integration of inorganic compounds during combustion makes these substitute fuels best suited for emission reduction and better clinker product. 
Alternative fuel used by the cement industry are mainly waste tyres, sewage sludge, animal residue, waste oil, paper residue, plastic, textile, and lumpy materials. In some cement kilns, 100\% substitution have been achieved, while in others, local waster market conditions do not allow for higher substitution rates [45]. Temperature profile and cooling conditions can also be altered with these fuels' inclusion. However, there are some practical limitations for the fuel substitution as the chemical properties of these fuels are different from the traditional fuels. For example, when tyre are burnt in the cement kiln, zinc oxide content increases in clinker that brings different components into the clinker via ashes, resulting in lower quality of the cement product such as lower setting time and lower strengths [46]. The problems in fuel substitution can be controlled by carefully monitoring the manufacturing process and allowing the raw materials to be burnt at a correct level, compensating the composition and optimum combustion in the kiln fed [47]. This will result in a better-quality clinker product that satisfy the cement standards. In some developed countries, use of alternative fuel has already moved from laboratory to the practical application [47], and higher substitution of $40-60 \%$ can be achieved in 2050, while for developing countries the values will be around 25-35\% [48]. As carbon dioxide emissions from fuels account for around $40 \%$ of total emissions, using alternative fuels can significantly reduce the emissions.

However, the achievements of high substitution rates face strong legal and political barriers. To utilize the non-fossil fuels, the cement industry must take permission from environmental regulation bodies. To acquire this, an environmental assessment has to be done to determine either utilizing waste would impact more than conventional resources or not [1]. Also, waste management legislation greatly impacts availability. Industrial waste is accumulating in such a huge quantity to the extent that giga-scale disposal has become a common phenomenon [49]. Higher substitutions are only possible if legislations restrict disposal of waste either in landfills or by incineration. In addition, the social acceptance of processing the waste for cement plant greatly affects the local collection. People have mostly misunderstood that co-processing emissions from waste will be higher even though emissions from a well developed and managed cement plant are significantly lower than the traditional fuels [50].

\subsection{Supplementary Cementitious Materials (SCMs)}

Supplementary cementitious materials (SCMs) can be used either as fillers or for their pozzolanic properties. They are composed of amorphous aluminosilicates, which react with excessive hydrated lime produced during cement hydration to form calcium aluminosilicate phase C-A-S-H [51]. These SCMs can either have a natural or industrial origin, where natural origin is further distinguished as natural and artificial pozzolans. Natural pozzolans are pyroclastic rocks and do not need pretreatment to react with calcium hydroxide. Their pozzolanic reactivity lies in rich silica content [52]. Common examples of silicate minerals are quartz, mica, pyroxene and feldspar. On the other hand, artificial pozzolans need prior activation to react with calcium hydroxide. Among artificial pozzolans are calcined clays, in which pozzolanic activity depends on the type and amount of calcined minerals, amount of impurities, activation method, and surface area after calcination [53]. The different kind of clay minerals are: kaolinite, illite, montmorillonite, and palygorskite [54,55]. Among the different types, kaolinite has the highest pozzolanic activity $[53,56]$. Several studies have highlighted the existence of an activation temperature for different clay minerals [57-60]. Habert recorded a temperature of $700{ }^{\circ} \mathrm{C}$ for kaolinite, $850^{\circ} \mathrm{C}$ for illite, $800{ }^{\circ} \mathrm{C}$ for montmorillonite, and $750{ }^{\circ} \mathrm{C}$ for palygorskite [59]. Although calcined kaolinite is an excellent candidate as supplementary cementitious material, the requirement of beneficiation treatment for the elimination of impurities during the manufacturing of metakaolin consumes energy, produces waste, and increases the cost of SCM [54].

The main industrial SCMs are blast furnace slag, fly ash, and, to a lesser scale, silica fume. Blast furnace slag is a by-product of iron industry which needs to be vitrified after the blast furnace processing to develop the binding properties. It contains calcium and magnesium aluminosilicates and higher content of $\mathrm{CaO}$, which allows production of the C-S-H phase. The global availability of blast 
furnace slag is around $330 \mathrm{Mt}$ (Million ton) per year [61]. The availability of slag has been decreased to $8 \%$ of cement production in 2014 compared to the $17 \%$ of cement production in 1980 [61]. With this low availability, it cannot replace the massively demanded clinker in some regions. The other important SCM is fly ash that results from the combustion in coal power plants. Fly ash mostly consists of silicon oxides but also contains significant quantities of aluminum oxides and iron oxide. The available amounts are greater than slag, around $900 \mathrm{Mt}$ per year, but due to a huge variation in quality only one-third of the produced quantity is used in the cement and concrete industry. Silica fume or micro silica is a by-product of silicon metal in electric arc furnace. Due to its high pozzolanic activity, it is utilized in high strength concretes. Due to its finer size it is helpful in making a denser microstructure of concrete. The global availability of silica fume is around $1 \mathrm{Mt}$ [62], which can be increased to an estimated quantity of $1.5 \mathrm{Mt}$ in 2020 [50]. Unfortunately, silica fume is an expansive product that is mainly used in high strength concretes, and with a limited production rate, it cannot be used for clinker substitution.

Among various SCMs available for substituting clinker, calcined clays, particularly in combination with lime stone (LC3 Technology), are found to be the extremely promising materials that are available in large enough amounts and have real potential to replace part of the clinker in cement production compared to the slag, which is available as $5 \%$ of the amount of clinker manufactured, and fly ash, whose amounts are greater than slag but due to variable quality is unsuitable for greater clinker substitution $[63,64]$. Clays are abundant materials worldwide and made up of silicon and aluminum oxides, which constitutes three quarters of the earth's crust [65]. The most suitable clays are kaolinite, which are widely available in equatorial to subtropical environments, which is where rapidly developing countries are located and where most of cement demand is likely to increase in the coming decades $[64,66]$. The pozzolanic activity of kaolinite is achieved when calcined at temperatures between 600 and $800{ }^{\circ} \mathrm{C}$ [55]. The potential of coupled substitution of limestone, calcined clay, and clinker (ternary blend) gave good mechanical performances at $50 \%$ clinker content [67].

\section{Alternative Binders}

The idea of alternative binders is to introduce different raw materials in clinker and cement manufacturing processes that will emit less $\mathrm{CO}_{2}$ and utilize less energy without compromising the efficiency and quality of cement. These resource efficient novel cements may include waste derived fuels and combination of different raw materials [47]. Engineering properties of these novel cements may be like those of conventional cements, making them a potential alternative. Below is a detailed description of potential alternative binders to the Portland cement.

\subsection{Alkali-Activated Cements}

Alkali-activated cements belong to family of hydraulic cements that are characterized by a high content of aluminosilicates bonding phase. Aluminosilicates are not reactive with water, or their reaction is too slow. However, due to their high amorphous content, they hydrolyze and condense when placed in alkaline medium, forming 3-D polymeric structures that have load-bearing ability [45]. In cements, the natural alkalinity of the system and portlandite fulfill these reactions, while in the absence of Portland cement, a strong base is needed to activate the amorphous aluminosilicates [45]. Alkali-activated cements are in competition to Portland cement in cost, performance, and less $\mathrm{CO}_{2}$ emissions. Furthermore, they proved to have more durability and ability to recycle the millions of tonnes of industrial by-products and waste. The prime materials used are blast furnace slag, steel slag, metakaolin, fly ash, kaolinitic clays, and red mud [19]. Various types of alkali-activated cements are currently available in market by different names, but their basic principle that applies is the same. Based upon the composition of cementitious components, alkali-activated cements are classified into five major categories [68]:

(1) Alkali-activated slag-based cements

(2) Alkali-activated pozzolan cements 
(3) Alkali-activated lime-pozzolan/slag cements

(4) Alkali-activated calcium aluminate blended cements

(5) Alkali-activated Portland blended cements

The mechanical properties of slag-based cement are governed by the nature of slag and type and dosage of activator used. Properly designed mixture of alkali-activated slag cement show higher strengths compared to OPC [69]. Among alkali-activated pozzolan cement, alkali-activated fly ash cement and alkali-activated metakaolin cement are of great interest. To synthesize geopolymer, fly ash or metakaolin and an alkali activator, such as sodium hydroxide, calcium hydroxide, or potassium hydroxide, are used [70]. The curing temperature of geopolymers usually ranges between $40{ }^{\circ} \mathrm{C}$ and $95{ }^{\circ} \mathrm{C}$, which is higher than that of Portland cement, which requires room temperature for curing [71-73]. Higher curing temperature promotes the reactivity of fly ash and results in higher early strength [74]. For metakaolin-based geopolymers, curing temperature is also crucial on setting and hardening. Elevated curing temperatures leads to higher early-age compressive and flexural strengths [75]. Geopolymers are found to be very resistive against acid and alkali-silica reaction and exhibit higher strengths when cured at higher temperature [70,76,77].

The readily available raw materials that contain aluminates and silicates are blast furnace slag and fly ash, which are produced as by-product, are utilized by "Zeobond" in Australia to manufacture low-emission geopolymer binders which are a sustainable alternative to the cement manufacturing [45]. Geopolymers are sometimes oversimplified to consider as pozzolanic cement. However, strength development through aluminosilicates as dominate phase and low porosity can distinguish it from other pozzolanic materials [40]. In spite of having a complex nomenclature, alkali-activated cements offer potential for huge environmental benefits since waste like slag, fly ash, alkaline sludge (red mud), and other non-pozzolanic materials can be used as precursor [71].

Many studies have reported that the environmental impacts of geopolymers are not significant compared to the OPC based on the aluminosilicates precursor used [78,79]. Alkali silicates form a glue that holds the particulates together resulting in a hardened chemically bonded product. The setting time is observed to be much faster than OPC and strength development mechanism is not the same as OPC $[80,81]$. While utilizing waste materials in cement production, maintaining a suitable chemical and physical balance in material properties is a challenging task that gets more challenging in the case of alkali-activated cements in which it is not apparent how waste materials will react in the presence of alkali. It is also claimed that presence of excessive alkali in alkali-activated cements can result in an alkali-silica reaction (ASR) [2]. However, studies have found that presence of alkali does not influence much to ASR occurrence, rather it is found to mitigate the phenomenon $[82,83]$. This is due to the competition of slag and aggregate for alkalis when there is small amount of $\mathrm{Ca}^{2+}$ in the pore solution. In this case, calcium silicate aluminate is the main product of alkali-activated slag with low Na and Al content. Later, at high alkali content, expansion occurred with formation of secondary reaction product (sodium and calcium silicate gel) [83].

\subsection{Belite-Rich Portland Cement}

The clinker mineralogy for belite-rich Portland cement is same as for OPC. They are also known as high belite cements. The key difference in modern Portland cement and the type of cement manufactured a century or more ago is the alite/belite ratio in clinker composition [84]. Belite content is more than $50 \%$ in belite-rich Portland cement, while alite constitutes about $35 \%$, which makes belite the abundant phase, compared to the conventional OPC where alite is the most abundant phase that constitutes around $50-65 \%$ and belite is only $15-30 \%$ [85]. These belite-rich cements defined under the Chinese standard GB200-300 are different from ASTM C150 Type 4 low heat cements in aspect of compressive strengths, as belite-rich cement showed $20 \%$ higher compressive strengths after 28 days curing compared to the conventional high belite cements [84]. It has been reported that high belite cement not only lowers the heat evolution but also shows excellent workability, higher mechanical properties and durability. It also exhibited better sulfate and chloride resistance, 
lower drying shrinkage, and delayed strength gain but higher ultimate strength at later age compared to traditional OPC [86-88].

Belite-rich cement are manufactured with same process as conventional OPC but with less amount of limestone in clinker raw mix. Alite formation requires high energy and therefore emits more $\left(\mathrm{RM}-\mathrm{CO}_{2}\right)$ compared to belite, thus manufacturing of belite-rich clinker results in less energy consumption and reduced $\mathrm{CO}_{2}$ emissions [61]. However, the reduction in emissions are around $10 \%$ which is not very convincing relative to conventional OPC [61]. The industrial production of belite-rich Portland cement is carried out in modern dry kilns with preheaters. It uses the same types of materials but mix design is different. Clinkering temperature inside the kiln is approximately $1350{ }^{\circ} \mathrm{C}$, which is $100{ }^{\circ} \mathrm{C}$ less than is needed for traditional OPC [84]. To make belite reactive, a physical (rapid clinker cooling) or chemical activation (element doping) is required in some cases. For example, an addition of $0.5-1.0 \% \mathrm{SO}_{3}$ in raw mix combined with clinker cooling results in formation of reactive belite. Due to low burning temperature, some low emissions are also observed $\left(\mathrm{NO}_{\mathrm{x}}\right.$ and $\left.\mathrm{SO}_{\mathrm{x}}\right)$. As the hardness of belite is relatively higher than the alite, around $5 \%$ more electric power is required to grind belite-rich cement to same fineness as OPC [84]. Heat generation during cement hydration has a significant effect on early strength gain on concrete, and a major reason to utilize belite-rich cement is that hydration of belite is nearly half of that of alite [89]. This means for an equivalent mix of concrete, maximum temperature with belite-rich cement will be lower than OPC. Lower temperature values are desirable in mass concrete work to avoid thermal cracking.

\subsection{Calcium Sulfoaluminate (CSA) Cement}

Calcium sulfoaluminate (CSA) cements are types of cements that contain high alumina content. To produce CSA clinker, bauxite, limestone, and gypsum are mixed together in a rotary kiln [2]. CSA cements were developed in China and came to prominence since the late 1970s. These cements were manufactured to control the swelling properties of the self-stressing concrete pipes [45]. The main constituents of the cement powder contain belite phase $\left(\mathrm{C}_{2} \mathrm{~S}\right)$, ye'elimite $\left(\mathrm{C}_{4} \mathrm{~A}_{3} \overline{\mathrm{S}}\right)$, and gypsum $\left(\mathrm{C} \overline{\mathrm{S}} \mathrm{H}_{2}\right)$ [90-92]. Upon hydration, $\mathrm{CSA}$ cements form ettringite according to the following reactions [93]. In absence of $\mathrm{Ca}(\mathrm{OH})_{2}$ :

$$
\mathrm{C}_{4} \mathrm{~A}_{3} \overline{\mathrm{S}}+2 \mathrm{C} \overline{\mathrm{S}} \mathrm{H}_{2}+36 \mathrm{H} \rightarrow \mathrm{C}_{6} \mathrm{AS}_{3} \mathrm{H}_{32}+2 \mathrm{AH}_{3}
$$

In presence of $\mathrm{Ca}(\mathrm{OH})_{2}$ :

$$
\mathrm{C}_{4} \mathrm{~A}_{3} \overline{\mathrm{S}}+8 \mathrm{C} \overline{\mathrm{S}} \mathrm{H}_{2}+6 \mathrm{CH}+74 \mathrm{H} \rightarrow 3 \mathrm{C}_{6} \mathrm{~A}_{3} \mathrm{H}_{32}
$$

The microstructure of the ettringite depends on the presence of lime [94]. Ettringite formed in Equation (2) is expansive in nature, which is exploited in self-stressing cement [95], while ettringite formed in Equation (3) is non-expansive and responsible for early strengths in cementitious composites [96]. The classical calcium sulfoaluminate clinkers are predominately based on $35-70 \%$ ye'elimite $\left(\mathrm{C}_{4} \mathrm{~A}_{3} \overline{\mathrm{S}}\right)$, $30 \%$ belite $\left(\beta-C_{2} S\right)$, with lesser percentages $10-30 \%$ of phases like, $C_{12} A_{7}, C_{4} A F$, and $C a O$, but $C_{2} A \bar{S}$ and $C \bar{S}$ are not desirable due to their deleterious nature [97]. By utilizing CSA compositions, limestone quantity is reduced in the kiln that not only benefits in reduced thermal energy (up to $25 \%$ ) but also decreased $\mathrm{CO}_{2}$ emissions (up to $20 \%$ ) compared to the Portland cement. Industrial waste materials can also be used as raw materials for manufacturing CSA cements $[98,99]$ and thus calcium sulfoaluminate cements have significant environmental advantages. Table 4 shows the amount of $\mathrm{CO}_{2}$ generated from the raw material conversion into OPC compared to various cement compounds [40]. Alite made from limestone and silica produces $0.578 \mathrm{~g}$ of $\mathrm{CO}_{2}$ per $\mathrm{g}$ of raw material, while calcium sulfoaluminate produces $0.216 \mathrm{~g}$ of $\mathrm{CO}_{2}$ per $\mathrm{g}$ of raw material prepared from limestone, alumina, and anhydrite. This make CSA clinker extremely attractive. However, the production of classical CSA has been stable at 1.2-1.3 Mt per year since 2004 [100]. The main reason is the excessive need of aluminum in raw materials to manufacture CSA 
clinker, which results in higher cost than OPC, thus limiting its application to acquire special properties (rapid hardening or self-stressing).

Table 4. The amount of carbon emissions produced from raw material conversion in Ordinary Portland Cement (OPC) compared to the various cement compounds. Reproduced from [40].

\begin{tabular}{ccc}
\hline Clinker Compounds & Raw Materials & $\mathbf{C O}_{\mathbf{2}}$ Emissions (g of $\mathbf{C O}_{\mathbf{2}}$ per $\mathbf{g}$ of Raw Material) \\
\hline Magnesia & Magnesite & 1.092 \\
Calcia (Lime) & Limestone & 0.785 \\
Alite & Limestone + silica & 0.578 \\
Belite & Limestone + silica & 0.511 \\
Tricalcium aluminate & Limestone + alumina & 0.489 \\
Calcium aluminoferrite & Same above + iron oxide & 0.362 \\
Sodium metasilicate & Soda + silica & 0.361 \\
Monocalcium aluminate & Limestone + alumina & 0.279 \\
Calcium aluminosilicate & Same above + anhydrite & 0.216 \\
\hline
\end{tabular}

\subsection{Belite-Calcium Sulfoaluminate Ferrite (BCSAF) or Belite-Ye'elimite-Ferrite (BYF) Cement}

The three essential phases in BCSAF or BYF technology are belite (dicalcium silicate, $\mathrm{C}_{2} \mathrm{~S}$ ), ye'elimite (calcium sulfoaluminate, $\mathrm{C}_{4} \mathrm{~A}_{3} \overline{\mathrm{S}}$ ), and ferrite (calcium alumino-ferrite, $\mathrm{C}_{4} \mathrm{AF}$ ). In this type of cement, belite and ye'elimite are major phases with belite preponderant, accompanied by significant amount of ye'elimite phase. The relative abundance of these phases in clinker is belite > ye'elimite > ferrite. Hydration phase for BYF cement is presented as follow [101].

Hydration reaction while $\mathrm{AH}_{3}$ is still available:

$$
\mathrm{C}_{2} \mathrm{~S}+\mathrm{AH}_{3}+5 \mathrm{H} \rightarrow \mathrm{C}_{2} \mathrm{ASH}_{8} \text { (strätlingite) }
$$

Hydration reaction at later ages:

$$
\begin{gathered}
\mathrm{C}_{2}(\mathrm{~A}, \mathrm{~F})+\mathrm{C}_{2} \mathrm{~S}+\mathrm{C}_{2} \mathrm{ASH}_{8} \rightarrow 2 \mathrm{C}_{3}(\mathrm{~A}, \mathrm{~F}) \mathrm{SH}_{4} \text { (katoite) } \\
2 \mathrm{C}_{2} \mathrm{~S}+7 \mathrm{H} \rightarrow \mathrm{C}_{3} \mathrm{~S}_{2} \mathrm{H}_{6}+\mathrm{CH} \\
2 \mathrm{C}_{2} \mathrm{~S} \cdot \mathrm{CS}+7 \mathrm{H} \rightarrow \mathrm{C}_{3} \mathrm{~S}_{2} \mathrm{H}_{6}+\mathrm{CH}+\mathrm{CS}
\end{gathered}
$$

In early age, strength generates from ettringite $\left(\mathrm{C}_{6} \mathrm{AS}_{3} \mathrm{H}_{32}\right)$ and aluminum hydroxide $\left(\mathrm{AH}_{3}\right)$ from the chemical reaction of ye'elimite $\left(\mathrm{C}_{4} \mathrm{~A}_{3} \overline{\mathrm{S}}\right)$ and anhydrite $(\mathrm{C} \overline{\mathrm{S}})$. After the exhaustion of anhydrite, further chemical reaction yields monosulfoaluminate $\left(\mathrm{C}_{4} \mathrm{~A} \overline{\mathrm{S}} \mathrm{H}_{12}\right)$ and aluminum hydroxide. Belite reacts with aluminum hydroxide to yield strätlingite $\left(\mathrm{C}_{2} \mathrm{ASH}_{8}\right)$ [101]. At this stage, no C-S-H is formed, and it shows the formed hydrates are different from conventional OPC systems. In later ages, further reaction of belite yields katoite $\left(\mathrm{C}_{3}(\mathrm{~A}, \mathrm{~F}) \mathrm{SH}_{4}\right)$ as $\mathrm{C}-\mathrm{S}-\mathrm{H}$ product. The BYF clinker approach is an extension to the previously established CSA cement technology and it is considered to be in between OPC and CSA cements [84]. These clinkers can be manufactured in traditional Portland cement plants with only changes needed in mix proportion, which is an advantage in terms of investment cost. The currently commercially available CSA cement has high ye'elimite content obtained from expansive aluminum rich raw materials, thus restricting its utilization to special properties such as shrinkage compensation and rapid strength that derive from ye'elimite phase [84]. The aim of developing BYF technology is to reduce the production cost of CSA clinkers. This is achieved by using less amount of aluminum rich materials while making stronger concrete products with low carbon emissions than concretes of similar characteristics made from traditional OPC [102].

The main difference in production of BYF cement and OPC is the proportion of various raw materials in the kiln. Both utilize limestone as principal raw material which provides calcium. However, BYF requires 20-30\% less limestone compare to OPC, resulting in less $\mathrm{CO}_{2}$ emissions [84]. Over half of $\mathrm{CO}_{2}$ emissions are from the rotary kiln during limestone calcination, which are reduced directly by 
utilizing lesser content of limestone compared to OPC. In contrast, BYF clinker require more aluminum content compare to the OPC manufacture, so aluminum-rich raw materials such as bauxites, coal, clays, and municipal waste are required for BYF clinker [61]. The additional work of bringing the aluminum-rich materials to the BYF clinker manufacturing site is reason why it is more expensive than traditional OPC as all current cement plants are near the quarry that provides raw materials for manufacturing of Portland cement. Lafarge proposed a clinker, registered as "Aerther", having higher belite content than CSA clinker, which allows utilization of less expensive raw materials in kiln feed [45]. These clinkers have the potential to replace the OPC clinker for all major applications with $\mathrm{CO}_{2}$ emission saving up to $20 \%$ by utilizing less limestone in clinker [61]. In addition, BYF clinker has potential to be manufactured in higher amounts compared to slag-cement, as it does not need a source of slag but still shows slag content similar to that of OPC. It can also replace slag-blended Portland cement in certain performance applications, as the CSA phase in BYF cements is very reactive and can develop high early strengths compared to slag-blended Portland cement [84]. It is evident from the results that BYF cements can be a promising alternative to traditional OPC.

BYF cements are preferred for special applications, since cements with higher content of belite than alite are less permeable and more resistant to chemical attacks [2]. Although, large belite content delays the setting time and strength development rate, but the presence of calcium aluminate and calcium sulfate compensates for this deficiency. An important environmental aspect linked to BYF cements is that it utilizes industrial by-products (e.g., fluidized bed combustor fly ash [103], flue gas desulfurization sludge [104], blast furnace slag, etc.) and sulfate content for clinker manufacturing process, which is not possible in the case of OPC clinker manufacturing. BYF cements can also use gypsum to form additional hydration products which have not been treated in a kiln, which will save considerable energy. BYF cements are still in the research and development phase and European cement companies, namely LafargeHolcim, Heidelberg, and Vicat, are actively conducting studies [101], but there are certain challenges existing that limit the competence of BYF clinker compare to OPC. The two significant technical challenges are related to reactivity control on different time scales; first is to get rapid strengths through ye'elimite hydration, and second, a smooth strength development gain over time through sufficiently reactive belite [101].

\subsection{Magnesium-Based Cements}

Magnesia cements are based on magnesium oxide $(\mathrm{MgO})$ as main reactive ingredient. It is developed by Sorel in 1867 and is known as "magnesite" or magnesium oxychloride cements [105]. At early stages, this type of cements was produced by using magnesium oxide and aqueous magnesium chloride. The resulting hardened product consists of four major bonding phases as: $2 \mathrm{Mg}(\mathrm{OH})_{2} \cdot \mathrm{MgCl}_{2} \cdot 4 \mathrm{H}_{2} \mathrm{O}, 3 \mathrm{Mg}(\mathrm{OH})_{2} \cdot \mathrm{MgCl}_{2} \cdot 8 \mathrm{H}_{2} \mathrm{O}, 5 \mathrm{Mg}(\mathrm{OH})_{2} \cdot \mathrm{MgCl}_{2} \cdot 5 \mathrm{H}_{2} \mathrm{O}$, and $9 \mathrm{Mg}(\mathrm{OH})_{2} \cdot$ $\mathrm{MgCl}_{2} \cdot \mathrm{H}_{2} \mathrm{O}$ [106]. However, it was soon recorded that magnesium oxychloride phase is not stable after an exposure to water over long time as it results into leaching out in form of magnesium chloride and magnesium oxide. This limits the practical application of the cement to certain properties in construction even though it showed high strength properties, high fire resistance, high abrasion, and exemption of wet curing [106] compared to traditional OPC. In the recent decade, after Harrison patented reactive $\mathrm{MgO}$ cements [107] the production has been significantly increased to $14 \mathrm{Mt}$ per year [108]. Magnesium oxysulfate cements, based on magnesium sulfate solution and magnesium oxide, has similar properties to Sorel cements [109], but poor weathering resistance has confined its utilization on mass scale.

Among different magnesia cements, magnesium carbonate cements got attention from the industry. They form in the presence of waste (e.g., slag, fly ash, silica fume, sewerage ash, and mine tailings), and provided brucite and accelerators are available [107]. The main reason for unsuitability of these abovementioned $\mathrm{MgO}$-based binder technologies is the scarcity of the raw material, as the principal source $\mathrm{MgO}$ is obtained by magnesite calcination $\left(\mathrm{MgCO}_{3}\right.$, rare mineral compared to $\left.\mathrm{CaCO}_{3}\right)$ and the huge amount of $\mathrm{CO}_{2}$ emissions during calcination of magnesium carbonate (see Table 4). 
However, the setting reaction from magnesia can consume $\mathrm{CO}_{2}$, which means this type of cement can act as a $\mathrm{CO}_{2}$ sink [2]. In 2008, an interesting approach was developed by the UK-based company Novacem in collaboration with Lafrange, to manufacture such cements from magnesium silicate rocks (e.g., olivine or serpentine), of which reservoirs are enormous and estimated to be more than 10,000 billion tonnes [110]. The process includes magnesium silicates, carbonated with $\mathrm{CO}_{2}$ at $200{ }^{\circ} \mathrm{C}$ and 180 bars to produce magnesium carbonate. Magnesium oxide is obtained after decarbonation at $700{ }^{\circ} \mathrm{C}$. The $\mathrm{CO}_{2}$ released at this stage is not fossil $\mathrm{CO}_{2}$, which indicates that manufacturing process is $\mathrm{CO}_{2}$ neutral [84]. The final Novacem cement composition is a mix of magnesium oxide, hydrated magnesium carbonates, and pozzolans. Some other potential carbonates that can be included are artinite, hydro magnesite, barringtonite, nesquehonite, dypingite, and lansfordite, which are produced in special reactors. This cement is also called "carbon negative cement" as the produced $\mathrm{CO}_{2}$ during production process is recycled back. In 2011, strength tests for concrete were carried out and 40-60 MPa strength like that produced by Portland cement could be achieved [45].

Despite the technical feasibility of Novacem's "carbon negative cement", it is known that magnesium oxide can be hardened directly by carbonation at modest $\mathrm{CO}_{2}$ pressures [111]. TecEco, an Australian company produced TecEco cements utilizing reactive magnesia also called caustic magnesia, in substitution to OPC [112]. Magnesia hydrates to brucite, which, upon exposure to atmosphere, carbonates to magnesium carbonate or magnesite [112]. Still, the key unresolved issue is to manufacture magnesium oxide from natural magnesium silicates rocks in an energy efficient way feasible to produce on industrial scale [113].

\subsection{Calcium Hydrosilicate-Based Cements (Celitement)}

Celitement is a new family of hydraulic cementitious binders. The materials and production process are developed by the Karlsruhe Institute of Technology (KIT). The raw materials, mixing and setting of these binders are similar to conventional cementitious binders [45]. It is based on amorphous hydraulic calcium hydrosilicates. The raw materials suitable for production of Celitement are carbonates (e.g., limestone) and silicates (e.g., slag, sand and fly ash). Calcination is done before processing. The carbonate content of raw material is in range of $40-50 \%$ compared to OPC where carbonate fraction is about $70 \%$. The $\mathrm{CaO} / \mathrm{SiO}_{2}$ ratio is between 1 and 2 . The ratios measured in concrete are referred to intercalation of $\mathrm{Ca}(\mathrm{OH})_{2}$ in calcium silicate hydrate [114]. Two stages are involved for processing raw materials. In the first stage, the raw materials are hydrothermally treated using an autoclave at around $150-200{ }^{\circ} \mathrm{C}$ and saturated steam pressure. This process produces hydrated calcium silicate compound $\left(\alpha-\mathrm{C}_{2} \mathrm{SH}\right)$. In the second stage, the synthesized calcium silicate hydrate is then blended and milled together with silicate components that produces amorphous calcium hydrosilicates [46]. The thermal treatment takes place at low temperature (150-200 $\left.{ }^{\circ} \mathrm{C}\right)$ compared to the OPC $\left(1450{ }^{\circ} \mathrm{C}\right)$. Reduction in energy demand is due to reduce carbonate content in mixture that reduces the $\mathrm{CO}_{2}$ emissions up to $50 \%$. Also, compressive strength up to $80 \mathrm{MPa}$ was achieved for mortar specimen at 28 days curing [115]. In 2011, a pilot production plant was constructed with help of Schwenk group that had a capacity of $100 \mathrm{~kg} /$ day [114]. However, the manufacturing process for Celitement is complex due to many processing steps involved compared to OPC production. This approach is still under laboratory development so no reliable estimate regarding overall energy efficiency and $\mathrm{CO}_{2}$ emissions in real-world industrial context can be made [61]. Table 5 shows the potential of different alternative cements that can be utilized for possible $\mathrm{CO}_{2}$ emissions reduction.

Table 5. The potential of alternative cements in $\mathrm{CO}_{2}$ reduction. Reproduced from [21].

\begin{tabular}{ccccc}
\hline Name & Type & Raw Material & Process Temperature & CO $_{2}$ Reduction \\
\hline Geopolymer & $\begin{array}{c}\text { Alkali activated } \\
\text { materials }\end{array}$ & $\begin{array}{c}\text { Fly ash, Al/Si wastes, } \\
\text { alkaline solutions }\end{array}$ & Ambient & Approx. 70\% \\
\hline $\begin{array}{c}\text { Sulfolauminate } \\
\text { cement }\end{array}$ & - & $\begin{array}{c}\text { Limestone, gypsum, } \\
\text { bauxite, sand/clay }\end{array}$ & $1200-1300{ }^{\circ} \mathrm{C}$ & $30-40 \%$ \\
\hline
\end{tabular}


Table 5. Cont.

\begin{tabular}{ccccc}
\hline Name & Type & Raw Material & Process Temperature & $\mathbf{C O}_{2}$ Reduction \\
\hline $\begin{array}{c}\text { Magnesia Binder } \\
\text { (Novacem) }\end{array}$ & Magnesium oxide & Magnesium silicates & $200{ }^{\circ} \mathrm{C}(180$ bar $)+700{ }^{\circ} \mathrm{C}$ & $>100 \%$ \\
\hline $\begin{array}{c}\text { Magnesia Binder } \\
\text { (TechEco) }\end{array}$ & $\begin{array}{c}\text { Magnesium oxide }+ \\
\text { OPC + fly ash }\end{array}$ & $\mathrm{MgCO}_{3}$ & $\begin{array}{c}<450{ }^{\circ} \mathrm{C} \\
(\mathrm{Tec}-\mathrm{Kiln})\end{array}$ & $>100 \%$ \\
\hline $\begin{array}{c}\text { Celitement (KIT) } \\
\text { hydrate }\end{array}$ & $\begin{array}{c}\text { As OPC (Ca/Si ratio 1-2) } \\
\text { hydrothermal) }\end{array}$ & Approx. 50\% \\
\hline $\begin{array}{c}\text { Carbonatable } \\
\text { Calcium Silicate } \\
\text { cement (Solidia) }\end{array}$ & $\begin{array}{c}\text { Calcium silicate } \\
\text { (wollastonite) }\end{array}$ & As OPC for cement & $1200{ }^{\circ} \mathrm{C}$ & Approx. $70 \%$ \\
\hline
\end{tabular}

\subsection{Carbonatable Calcium Silicate Cement}

Calcium silicates can be hardened by carbonation as well as by hydration. In ancient times, lime-based binders are hardened by atmospheric carbonation, but the process was very slow as the atmosphere contains around $440 \mathrm{ppm} \mathrm{CO}_{2}$ - an increase of around $50 \%$ value on its ancient time but still less compared to water vapor [84]. In addition, the inward carbonation from outside by diffusion leads to non-homogenous hardening profile that can be problematic for bulk concretes. Partial carbonation curing is already in application for some precast concrete plants, which boosts in strength compared to humid curing. However, this method consumes less $\mathrm{CO}_{2}$. The development of special carbonatable calcium silicate clinkers (CCSC) technology has been advanced by improving the carbonation process without utilizing excessive energy (Solidia, USA) [116]. The CCSC clinkers can be made in conventional cement kilns utilizing low-lime calcium silicate minerals such as wollastonite $\left(\mathrm{CaSiO}_{3}, \mathrm{CS}\right)$. These clinkers require approximately $45 \% \mathrm{CaO}$ compare to $70 \% \mathrm{CaO}$ required in case of OPC that results a $30 \%$ reduction in $\mathrm{CO}_{2}$ emissions from material source. Furthermore, the temperature required for synthesizing these clinkers is around $1200^{\circ} \mathrm{C}$, whereas it is $1450{ }^{\circ} \mathrm{C}$ in case of OPC sintering. The low kiln temperature also yields $30 \%$ reduction in $\mathrm{CO}_{2}$ emissions [116]. The clinker produced is unreactive to harden simply by hydration and can only be cured in relatively pure $\mathrm{CO}_{2}$ gas, provided with controlled temperature and relative humidity. This requires some modifications in the curing chambers and involves some capital cost. The CCSC have shown high strength gain for $24 \mathrm{~h}$ compared to OPC strengths reached at 28 days for identical mix design. The evaporated water from fresh concrete is recaptured during the curing process, thus CSSC concrete consumes much less water [84]. However, due to need of a specialized curing procedure, concretes using this type of cement are not capable to protect steel against corrosion (because of low $\mathrm{PH} \approx 9$ ) and limits its application for only non-reinforced cement products $[61,84]$.

\subsection{Life Cycle Assessment}

Life cycle assessment (LCA) is a method that evaluates the environmental aspects and impacts of materials, products, and technologies through product's life cycle $[117,118]$. LCA procedure is specified in ISO 14,040-14,044 [119,120]. According to these standards, the four main stages of a LCA study are: goal and scope definition, inventory analysis, impact assessment, and interpretation. Life cycle assessment of cement includes but not limited to: raw materials acquisition, manufacture, construction and residual materials [121]. It then estimates the relative impacts they have on greenhouse gas emissions, ozone depletion, photo-oxidants formation and terrestrial acidification [122]. There are a number of studies conducted on life cycle assessment of clinker production [122-125]. However, very limited LCA studies are available for alternative cements. The first LCA study on geopolymers was published in 2009 [78]. In this study, $1 \mathrm{~m}^{3}$ of geopolymer (made with slag/fly ash) is compared to $1 \mathrm{~m}^{3}$ concrete. The three major impact categories studied were abiotic depletion potential (ADP), global warming potential (GWP), and cumulative energy demand (CED) [78]. Geopolymer outperformed the concrete specimen in GWP by a factor of 3 while impact on resources depletion and energy 
consumption were similar. For calcium sulfoaluminate clinker, the only available information on LCA is a commercial document by Italcementi Group [126]. The global warming potential of CSA clinker with $18 \%$ gypsum source is $721 \mathrm{~kg} \mathrm{CO}$ eq/ton, while when blended with $30 \%$ gypsum source, it represents $599 \mathrm{~kg} \mathrm{CO}_{2} \mathrm{eq} /$ ton compared to Portland cement $844 \mathrm{~kg} \mathrm{CO}_{2} \mathrm{eq} / \mathrm{ton}$ [126].

\section{Conclusions}

The present study has reviewed and discussed a range of alternative approaches to mitigate $\mathrm{CO}_{2}$ emissions linked to the production of binder phase. These range from replacing the conventional raw materials and fuels used for Portland cement production to complete replacement of cement clinker with novel clinker, such as sulfoaluminate cements and magnesia cements. In addition, an efficient use of binders' components in terms of environmental impact is also highlighted. Seven alternative cements are discussed in detail and their relative position to the conventional Portland cement has been made. In the short term, advance technological and experimental methods are needed to establish the crucial response of these alternative cements. These alternative binders are supposed to provide a simple yet promising solution for OPC replacement by competing the cost at industrial scale. This potential of novel binder can be fully realized only through detailed investigation and characterization of binder with help of cutting-edge technologies. Establishing codes, standards, and setting guidelines with trainings will play a key role in developing alternative cement concept.

Ultimately, the approaches to enhance the sustainability of cement production depends upon the economic, strategic planning vision from industry owners and government. With globally binding agreements, introducing incentives for potentially effective options $\left(\mathrm{CO}_{2}\right.$ emissions reduction) and an emphasis shift to long run benefits will result in developing and familiarity of alternative binders.

Author Contributions: A.N. analyzed data and wrote the paper under supervision of J.G.J.

Funding: This work was supported by the National Research Foundation of Korea (NRF) grant funded by the Korea government (MSIT) (No. 2018R1C1B6002093).

Acknowledgments: We acknowledge the National Research Foundation of Korea (NRF) and the Korea government (MSIT).

Conflicts of Interest: The authors declare no conflict of interest.

\section{References}

1. Imbabi, M.S.; Carrigan, C.; McKenna, S. Trends and developments in green cement and concrete technology. Int. J. Sustain. Built Environ. 2012, 1, 194-216. [CrossRef]

2. Phair, J.W. Green chemistry for sustainable cement production and use. Green Chem. 2006, 8, 763-780. [CrossRef]

3. U.S. Geological Survey. Mineral Commodity Summaries 2018; U.S. Geological Survey: Reston, VA, USA, 2018.

4. Smith, R.A.; Kersey, J.R.; Griffiths, P.J. The Construction Industry Mass Balance: Resource use, wastes and emissions. Construction 2002, 4, 680 .

5. World Business Council for Sustainable Development. Toward a Sustainable Cement Industry. March 2002. Available online: http:/ / citeseerx.ist.psu.edu/viewdoc/download?rep=rep1\&type=pdf\&doi=10.1.1.123. 3145 (accessed on 24 October 2018).

6. Mehta, P.K.; Monteiro, P.J.M. Concrete Microstructure, Properties, and Materials, 3rd ed.; McGraw-Hill: New York, NY, USA, 2006; ISBN 0071589198.

7. Hasanbeigi, A.; Price, L.; Lu, H.; Lan, W. Analysis of energy-efficiency opportunities for the cement industry in Shandong Province, China: A case study of 16 cement plants. Energy 2010, 35, 3461-3473. [CrossRef]

8. Turner, L.K.; Collins, F.G. Carbon dioxide equivalent $\left(\mathrm{CO}_{2}-\mathrm{e}\right)$ emissions: A comparison between geopolymer and OPC cement concrete. Constr. Build. Mater. 2013, 43, 125-130. [CrossRef]

9. Valipour, M.; Yekkalar, M.; Shekarchi, M.; Panahi, S. Environmental assessment of green concrete containing natural zeolite on the global warming index in marine environments. J. Clean. Prod. 2014, 65, 418-423. [CrossRef] 
10. Rashad, A.M.; Zeedan, S.R. The effect of activator concentration on the residual strength of alkali-activated fly ash pastes subjected to thermal load. Constr. Build. Mater. 2011, 25, 3098-3107. [CrossRef]

11. Rashad, A.M. An exploratory study on high-volume fly ash concrete incorporating silica fume subjected to thermal loads. J. Clean. Prod. 2015, 87, 735-744. [CrossRef]

12. Rashad, A.M.; Bai, Y.; Basheer, P.A.M.; Milestone, N.B.; Collier, N.C. Hydration and properties of sodium sulfate activated slag. Cem. Concr. Compos. 2013, 37, 20-29. [CrossRef]

13. Lund, P. Impacts of EU carbon emission trade directive on energy-intensive industries-Indicative micro-economic analyses. Ecol. Econ. 2007, 63, 799-806. [CrossRef]

14. World Business Council for Sustainable Development. The Cement Sustainability Initiative, Cement Industry Energy and CO2 Performance: "Getting the Numbers Right"; WBCSD: Geneva, Switzerland, 2009; Volume 44, ISBN 978-3-940388-48-3.

15. Kartini, K.; Hamidah, M.S.; Norhana, A.R.; Nur Hanani, A.R. Quarry dust fine powder as substitute for ordinary portland cement in concrete mix. J. Eng. Sci. Technol. 2014, 9, 191-205.

16. Yang, K.H.; Jung, Y.B.; Cho, M.S.; Tae, S.H. Effect of Supplementary Cementitious Materials on Reduction of CO2Emissions From Concrete. Handb. Low Carbon Concr. 2016, 103, 89-110. [CrossRef]

17. Crossin, E. The greenhouse gas implications of using ground granulated blast furnace slag as a cement substitute. J. Clean. Prod. 2015, 95, 101-108. [CrossRef]

18. European Commission DG A New Approach to Evaluating the Sustainability of Substituting Raw Materials: Science for Environmental Policy; The University of the West of England: Bristol, UK, 2018.

19. Li, C.; Sun, H.; Li, L. A review: The comparison between alkali-activated slag ( $\mathrm{Si}+\mathrm{Ca})$ and metakaolin $(\mathrm{Si}+\mathrm{Al})$ cements. Cem. Concr. Res. 2010, 40, 1341-1349. [CrossRef]

20. Pacheco-Torgal, F.; Castro-Gomes, J.; Jalali, S. Alkali-activated binders: A review. Part 1. Historical background, terminology, reaction mechanisms and hydration products. Constr. Build. Mater. 2008, 22, 1305-1314. [CrossRef]

21. Ojan, M.; Montenegro, P.; Borsa, M.; Altert, C.; Fielding, R. Development of New Types of Low Carbon Cement. 2016. Available online: https:/ / www.wbcsd.org/Sector-Projects/Cement-Sustainability-Initiative/ News/CSI-climate-and-energy-workshop (accessed on 24 October 2018).

22. Scrivener, K.L. Eco-efficient cements: Potential economically viable solutions for a low- $\mathrm{CO}_{2}$ cement-based materials industry. Cem. Concr. Res. 2016. [CrossRef]

23. Bontempi, E. A new approach for evaluating the sustainability of raw materials substitution based on embodied energy and the CO2 footprint. J. Clean. Prod. 2017, 162, 162-169. [CrossRef]

24. Bontempi, E. A New Approach to Evaluate the Sustainability of Raw Materials Substitution. In Raw Materials Substitution Sustainability; Springer: Cham, Switzerland, 2017; ISBN 978-3-319-60830-3.

25. Bosoaga, A.; Masek, O.; Oakey, J.E. CO2 Capture Technologies for Cement Industry. Energy Procedia 2009. [CrossRef]

26. Gartner, E.M.; MacPhee, D.E. A physico-chemical basis for novel cementitious binders. Cem. Concr. Res. 2011, 41, 736-749. [CrossRef]

27. Damtoft, J.S.; Herfort, D.; Yde, E. Concrete Binders, Mineral Additions and Chemical Admixtures: State of the Art and Challenges for the 21st Century; University of Dundee: Scotland, UK, 2006.

28. Mindess, S.; Young, J.F.; Darwin, D. Concrete; Prentice Hall, Pearson Education, Inc.: Upper Saddle River, NJ, USA, 2003; p. 644. ISBN 9780130646323.

29. Valderrama, C.; Granados, R.; Cortina, J.L.; Gasol, C.M.; Guillem, M.; Josa, A. Implementation of best available techniques in cement manufacturing: A life-cycle assessment study. J. Clean. Prod. 2012, 25, 60-67. [CrossRef]

30. Josa, A.; Aguado, A.; Cardim, A.; Byars, E. Comparative analysis of the life cycle impact assessment of available cement inventories in the EU. Cem. Concr. Res. 2007, 37, 781-788. [CrossRef]

31. Von Bahr, B.; Hanssen, O.J.; Vold, M.; Pott, G.; Stoltenberg-Hansson, E.; Steen, B. Experiences of environmental performance evaluation in the cement industry. Data quality of environmental performance indicators as a limiting factor for benchmarking and rating. J. Clean. Prod. 2003, 11, 713-725. [CrossRef]

32. Boesch, M.E.; Hellweg, S. Identifying improvement potentials in cement production with life cycle assessment. Environ. Sci. Technol. 2010, 44, 9143-9149. [CrossRef] [PubMed]

33. Humpher, K. Toward a Sustainable Cement Industry. Sub-Study 8: Climate Change; WBCSD: Geneva, Switzerland, 2002. 
34. Hendriks, C.A.; Worrell, E.; de Jager, D.; Block, K.; Riemer, P. Emission Reduction of Greenhouse Gases from the Cement Industry. In Proceedings of the IEA Greenhouse Gas Control Technologies Conference, Vancouver, BC, Canada, 5-9 September 2004.

35. Josa, A.; Aguado, A.; Heino, A.; Byars, E.; Cardim, A. Comparative analysis of available life cycle inventories of cement in the $\{\mathrm{EU}\}$. Cem. Concr. Res. 2004, 34, 1313-1320. [CrossRef]

36. Flower, D.J.M.; Sanjayan, J.G. Greenhouse Gas Emissions Due to Concrete Manufacture. Handb. Low Carbon Concr. 2016, 12, 1-16. [CrossRef]

37. Chen, C.; Habert, G.; Bouzidi, Y.; Jullien, A. Environmental impact of cement production: Detail of the different processes and cement plant variability evaluation. J. Clean. Prod. 2010, 18, 478-485. [CrossRef]

38. ATILH. Environmental Inventory of French Cement Production; ATILH: Paris, France, 2002.

39. Van Oss, H.G.; Padovani, A.C. Cement manufacture and the environment, Part II: Environmental challenges and opportunities. J. Ind. Ecol. 2003, 7, 93-126. [CrossRef]

40. Gartner, E. Industrially interesting approaches to "low- $\mathrm{CO}_{2}$ " cements. Cem. Concr. Res. 2004, 34, 1489-1498. [CrossRef]

41. Huntzinger, D.N.; Eatmon, T.D. A life-cycle assessment of Portland cement manufacturing: Comparing the traditional process with alternative technologies. J. Clean. Prod. 2009, 17, 668-675. [CrossRef]

42. Febelcem, v.z.w. Environmental Report of the Belgian Cement Industry; Febelcem, v.z.w.: Brussels, Belgium, 2006.

43. Damtoft, J.S.; Lukasik, J.; Herfort, D.; Sorrentino, D.; Gartner, E.M. Sustainable development and climate change initiatives Original Research Article. Cem. Concr. Res. 2008, 38, 115-127. [CrossRef]

44. Habert, G.; Billard, C.; Rossi, P.; Chen, C.; Roussel, N. Cement production technology improvement compared to factor 4 objectives. Cem. Concr. Res. 2010, 40, 820-826. [CrossRef]

45. Habert, G. Assessing the environmental impact of conventional and 'green'cement production. Eco-Effic. Constr. Build. Mater. 2014, 199-238. [CrossRef]

46. Schneider, M.; Romer, M.; Tschudin, M.; Bolio, H. Sustainable cement production-present and future. Cem. Concr. Res. 2011, 41, 642-650. [CrossRef]

47. MPA Cement Fact Sheet. Novel Cements: Low Energy, Low Carbon Cements. 1-9. Available online: https:/ / cement.mineralproducts.org/documents/FS_12_Novel_cements_low_energy_low_carbon_ cements.pdf (accessed on 6 Novemebr 2018).

48. World Business Council for Sustainable Development. Cement Technology Roadmap 2009, Carbon Emissions Reductions up to 2050. Available online: https: / www.iea.org/publications / freepublications / publication/ Cement.pdf (accessed on 6 November 2018).

49. Della, E.S.; Grutzeck, M.W. Giga-scale disposal: A real frontier for ceramic research. Mater. Res. Innov. 1999, 3, 55-56.

50. Rovira, J.; Mari, M.; Nadal, M.; Schuhmacher, M.; Domingo, J.L. Science of the Total Environment Partial replacement of fossil fuel in a cement plant: Risk assessment for the population living in the neighborhood. Sci. Total Environ. 2010, 408, 5372-5380. [CrossRef]

51. Papadakis, V.G.; Fardis, M.N.; Vayenas, C.G. Hydration and carbonation of pozzolanic cements. Mater. J. 1992, 89, 109-130.

52. Habert, G.; Choupay, N.; Montel, J.M.; Guillaume, D.; Escadeillas, G. Effects of the secondary minerals of the natural pozzolans on their pozzolanic activity. Cem. Concr. Res. 2008, 38, 963-975. [CrossRef]

53. Tironi, A.; Trezza, M.A.; Scian, A.N.; Irassar, E.F. Assessment of pozzolanic activity of different calcined clays. Cem. Concr. Compos. 2013, 37, 319-327. [CrossRef]

54. Taylor-Lange, S.C.; Lamon, E.L.; Riding, K.A.; Juenger, M.C.G. Calcined kaolinite-bentonite clay blends as supplementary cementitious materials. Appl. Clay Sci. 2015, 108, 84-93. [CrossRef]

55. Fernandez, R.; Martirena, F.; Scrivener, K.L. The origin of the pozzolanic activity of calcined clay minerals: A comparison between kaolinite, illite and montmorillonite. Cem. Concr. Res. 2011, 41, 113-122. [CrossRef]

56. Garg, N.; Skibsted, J. Thermal activation of a pure montmorillonite clay and its reactivity in cementitious systems. J. Phys. Chem. C 2014, 118, 11464-11477. [CrossRef]

57. He, C.; Makovicky, E.; Osbæck, B. Thermal stability and pozzolanic activity of raw and calcined mixed-layer mica/smectite. Appl. Clay Sci. 2000, 17, 141-161. [CrossRef]

58. Kakali, G.; Perraki, T.; Tsivilis, S.; Badogiannis, E. Thermal treatment of kaolin: The effect of mineralogy on the pozzolanic activity. Appl. Clay Sci. 2001, 20, 73-80. [CrossRef] 
59. Habert, G.; Choupay, N.; Escadeillas, G.; Guillaume, D.; Montel, J.M. Clay content of argillites: Influence on cement based mortars. Appl. Clay Sci. 2009, 43, 322-330. [CrossRef]

60. Donatello, S.; Tyrer, M.; Cheeseman, C.R. Comparison of test methods to assess pozzolanic activity. Cem. Concr. Compos. 2010, 32, 121-127. [CrossRef]

61. Scrivener, K.L.; John, V.M.; Gartner, E.M. Eco-efficient cements: Potential economically viable solutions for a low-CO2cement-based materials industry. Cem. Concr. Res. 2018. [CrossRef]

62. Khatib, J.M. Sustainability of Construction Materials; Woodhead Publishing Limited: Cambridge, UK, 2009.

63. Sánchez Berriel, S.; Favier, A.; Rosa Domínguez, E.; Sánchez MacHado, I.R.; Heierli, U.; Scrivener, K.; Martirena Hernández, F.; Habert, G. Assessing the environmental and economic potential of Limestone Calcined Clay Cement in Cuba. J. Clean. Prod. 2016, 124, 361-369. [CrossRef]

64. Scrivener, K.; Martirena, F.; Bishnoi, S.; Maity, S. Calcined clay limestone cements (LC3). Cem. Concr. Res. 2017, 114, 49-56. [CrossRef]

65. Scrivener, K.L. 202 Special Issue-Options for the future of cement. Indian Concr. J. 2014, 88, 11-21. [CrossRef]

66. Scrivener, K.L.; Avet, F.; Maraghechi, H.; Zunino, F.; Ston, J.; Favier, A.; Hanpongpun, W. Impacting factors and properties of Limestone Calcined Clay Cements (LC3). In Green Materials; ICE Publishing: London, UK, 2018.

67. Antoni, M.; Rossen, J.; Martirena, F.; Scrivener, K. Cement substitution by a combination of metakaolin and limestone. Cem. Concr. Res. 2012, 42, 1579-1589. [CrossRef]

68. Shi, C.; Jiménez, A.F.; Palomo, A. New cements for the 21st century: The pursuit of an alternative to Portland cement. Cem. Concr. Res. 2011, 41, 750-763. [CrossRef]

69. Shi, C.; Krivenko, P.V.; Roy, D. Alkali-Activated Cements and Concrete; Taylor \& Francis: New York, NY, USA, 2006; ISBN 978-0-415-70004-7.

70. Provis, J.L. Geopolymers and other alkali activated materials: Why, how, and what? Mater. Struct. Constr. 2014, 47, 11-25. [CrossRef]

71. Khale, D.; Chaudhary, R. Mechanism of geopolymerization and factors influencing its development: A review. J. Mater. Sci. 2007, 42, 729-746. [CrossRef]

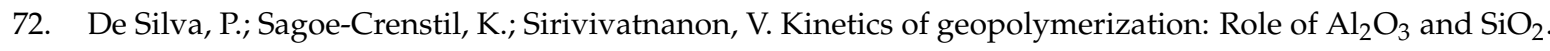
Cem. Concr. Res. 2007, 37, 512-518. [CrossRef]

73. Somna, K.; Jaturapitakkul, C.; Kajitvichyanukul, P.; Chindaprasirt, P. NaOH-activated ground fly ash geopolymer cured at ambient temperature. Fuel 2011, 90, 2118-2124. [CrossRef]

74. Kovalchuk, G.; Fernández-Jiménez, A.; Palomo, A. Alkali-activated fly ash: Effect of thermal curing conditions on mechanical and microstructural development-Part II. Fuel 2007, 86, 315-322. [CrossRef]

75. Rovnaník, P. Effect of curing temperature on the development of hard structure of metakaolin-based geopolymer. Constr. Build. Mater. 2010, 24, 1176-1183. [CrossRef]

76. Jang, J.G.; Ahn, Y.B.; Souri, H.; Lee, H.K. A novel eco-friendly porous concrete fabricated with coal ash and geopolymeric binder: Heavy metal leaching characteristics and compressive strength. Constr. Build. Mater. 2015, 79, 173-181. [CrossRef]

77. Barbosa, V.F.F.; MacKenzie, K.J.D. Thermal behaviour of inorganic geopolymers and composites derived from sodium polysialate. Mater. Res. Bull. 2003, 38, 319-331. [CrossRef]

78. Weil, M.; Dombrowski, K.; Buchwald, A. Life-cycle analysis of geopolymers. In Geopolymers; Woodhead Publishing Limited: Cambridge, UK, 2009; pp. 194-210.

79. Habert, G.; Espinose, J.B.; Lacaillerie, D.; Roussel, N. An environmental evaluation of geopolymer based concrete production: Reviewing current research trends. J. Clean. Prod. 2011, 19, 1229-1238. [CrossRef]

80. Jang, J.G.; Lee, N.K.; Lee, H.K. Fresh and hardened properties of alkali-activated fly ash/slag pastes with superplasticizers. Constr. Build. Mater. 2014, 50, 169-176. [CrossRef]

81. Park, S.M.; Jang, J.G.; Lee, H.K. Unlocking the role of $\mathrm{MgO}$ in the carbonation of alkali-activated slag cement. Inorg. Chem. Front. 2018, 5, 1661-1670. [CrossRef]

82. Xie, Z.; Xiang, W.; Xi, Y. ASR Potentials of Glass Aggregates in Water-Glass Activated Fly Ash and Portland Cement Mortars. J. Mater. Civ. Eng. 2003, 15. [CrossRef]

83. Ferna, A. The alkali-Silica reaction in alkali-activated granulated slag mortars with reactive aggregate. Cem. Concr. Res. 2002, 32, 1019-1024.

84. Gartner, E.; Sui, T. Alternative cement clinkers. Cem. Concr. Res. 2018, 114, 27-39. [CrossRef] 
85. Sui, T.; Li, J.; Peng, X.; Li, W.; Wen, Z.; Wang, J.; Fan, L. A Comparison of HBC \& MHC Massive Concretes for Three Gorges Project in China. In Measuring, Monitoring and Modeling Concrete Properties; Springer: Dordrecht, The Netherlands, 2006; pp. 341-342.

86. Sui, T.; Fan, L.; Wen, Z.; Wang, J. Properties of Belite-Rich Portland Cement and Concrete in China. J. Civ. Eng. Arch. 2015, 9, 384-392. [CrossRef]

87. Sui, T.; Liu, K. Study on the properties of High-Belite cement. J. Chin. Ceram. Soc. 1999, 488-492.

88. Jang, J.G.; Lee, H.K. Microstructural densification and $\mathrm{CO}_{2}$ uptake promoted by the carbonation curing of belite-rich Portland cement. Cem. Concr. Res. 2016, 82, 50-57. [CrossRef]

89. Taylor, H.F.W. Cement Chemistry; Academic Press: London, UK, 1990.

90. Chatterjee, A.K. Structure and Performance Cements. In Special Cements; Bensted, J., Barnes, P., Eds.; E \& FN Spon: London, UK, 2002; pp. 226-231.

91. Glasser, F.P.; Zhang, L. High-performance cement matrices based on calcium sulfoaluminate-Belite compositions. Cem. Concr. Res. 2001, 31, 1881-1886. [CrossRef]

92. Lan, W.; Glasser, F.P. Hydration of calcium sulphoaluminate cements. Adv. Cem. Res. 1996, 8, 127-134. [CrossRef]

93. Older, I. Cements containing calcium sulfoaluminate. In Special Inorganic Cements; Bentur, A., Mindess, S., Eds.; E \& FN Spon: London, UK, 2000; pp. 69-87.

94. Mehta, P.K. Mechanism of expansion associated with ettringite formation. Cem. Concr. Res. 1973. [CrossRef]

95. Su, M.; Kurdowski, W. Development in non- Portland cements. In Proceedings of the 9th International Congress on the Chemistry of Cement, New Dehli, India, 1992; pp. 317-354. Available online: https: / / catalog.hathitrust.org/Record/ 009223995 (accessed on 18 Janaury 2019).

96. Beretka, J.; Sherman, N.; Marrocooli, M.; Pompo, A. Effect of composition on the hydration properties of rapid-hardening silfoaluminate cements. In Proceedings of the 10th International Congress on the Chemistry of Cement, Gothenburg, Sweden, 2-6 June 1997.

97. Factsheet, M.P. Mineral Planning Factsheet. 2014. Available online: https://www.bgs.ac.uk/downloads / start.cfm?id=1353 (accessed on 14 November 2018).

98. Ambroise, J. Immobilization of calcium sulfate contained in demolition waste. J. Hazard. Mater. 2008, 151, 840-846. [CrossRef] [PubMed]

99. Zhang, L.; Muzhen, S.; Yanmou, W. Development and use of sulfo and ferro aluminate cements in China. Adv. Cem. Res. 1999, 11, 15-21. [CrossRef]

100. Diao, J. Actuality and perspective of Chinese CSA development (in Chinese). J. Chin. Concr. Cem. Assoc. 2008.

101. Gartner, E. What are BYF cements, and how do they differ from CSA cements? In Proceedings of the Future of Cement, 200 Years after Louis Vicat, UNESCO, Paris, France, 6-8 June 2017.

102. Barcelo, L.; Kline, J.; Walenta, G.; Gartner, E. Cement and carbon emissions. Mater. Sci. 2014, 47, $1055-1065$. [CrossRef]

103. Majling, J.; Roy, D.M. The potential of fly ash for cement manufacture. Am. Ceram. Soc. Bull. 1993, 72, 45-50.

104. Arjunan, P.; Silsbee, M.R.; Roy, D.M. Sulfoaluminate-belite cement from low-calcium fly ash and sulfur-rich and other industrial by-products. Cem. Concr. Res. 1999, 29, 1305-1311. [CrossRef]

105. Sorel, S.; Hebd, C.R. Sorel cement. CR Hebd. Seances Acad. Sci. 1867, 65, 102.

106. Maravelaki-kalaitzaki, P.; Moraitou, G. Sorel's cement mortars Decay susceptibility and effect on Pentelic marble. Cem. Concr. Res. 2000, 29, 1929-1935. [CrossRef]

107. Harrison, A.J.W. New cement based on the addition of reactive magnesia to Portland cement with or without added pozzolana. In Proceedings of the CIA Conference: Concrete in the Third Millennium, Brisbane, Australia, 17-19 July 2003; Available online: http:/ / www.tececo.com/document.conference_presentations. php (accessed on 29 November 2018).

108. USGS. United States Geological Survey. 2012. Available online: https://minerals.usgs.gov/minerals (accessed on 29 November 2018).

109. Daspoddar, K.; Chowdhry, B.N.; Basu, R. Effect of Calcination Temperature of Magnesium carbonate on the Propertiesof Magnesium Oxysulphate Cement. J. Indian Chem. Soc. 1992, 550-551.

110. Lackner, K.S. Erratum: A guide to $\mathrm{CO}_{2}$ sequestration. Science 2003, 300, 1677-1678. Available online: http:/ / science.sciencemag.org/content/300/5626/1677.long (accessed on 29 November 2018). [CrossRef] [PubMed] 
111. Liska, M.; Vandeperre, L.J. Influence of carbonation on the properties of reactive magnesia cement-based pressed masonry units. Adv. Cem. Res. 2008, 20, 53-64. [CrossRef]

112. TecEco Pty Ltd. TecEco Cements; TecEco Pty Ltd.: Glenorchy, Australia, 2013.

113. Gartner, E.; Hirao, H. Cement and Concrete Research A review of alternative approaches to the reduction of $\mathrm{CO}_{2}$ emissions associated with the manufacture of the binder phase in concrete. Cem. Concr. Res. 2015, 78, 126-142. [CrossRef]

114. Stemmermann, P.; Beuchle, G.; Garbev, K.; Schweike, U.C. A new sustainable hydraulic binder based on calcium hydrosilicates. In Proceedings of the 13th international Congress on the Chemistry of Cement, Madrid Spain, 13 June 2011.

115. Stemmermann, P.; Schweike, U.; Garbev, K.; Beuchle, G. Celitement-A sustainable prospect for the cement industry. Cem. Int. 2010, 8, 52-66.

116. Atakan, V.; Sahu, S.; Quinn, S.; Xudongh, H. Why CO2 Matters-Advances in a New Class of Cement; Solidia Technologies: Piscataway, NJ, USA, 2014; Available online: http:/ / solidiatech.com/wp-content/uploads/ 2014/03/ZKG_Sonderdruck_Solidia_Technologie_print.pdf (accessed on 3 December 2018).

117. Rebitzer, G.; Ekvall, T.; Frischknecht, R.; Hunkeler, D.; Norris, G.; Rydberg, T.; Schmidt, W.P.; Suh, S.; Weidema, B.P.; Pennington, D.W. Life cycle assessment Part 1: Framework, goal and scope definition, inventory analysis, and applications. Environ. Int. 2004, 30, 701-720. [CrossRef] [PubMed]

118. Pennington, D.W.; Potting, J.; Finnveden, G.; Lindeijer, E.; Jolliet, O.; Rydberg, T.; Rebitzer, G. Life cycle assessment Part 2: Current impact assessment practice. Environ. Int. 2004, 30, 721-739. [CrossRef] [PubMed]

119. ISO, 14040: Environmental Management-Life Cycle Assessment-Principles and Framwork; ISO: London, UK, 2006.

120. ISO, 14044: Environmental Management-Life Cycle Assessment-Requirements and Guidelines; ISO: London, UK, 2006.

121. Gäbel, K.; Forsberg, P.; Tillman, A.M. The design and building of a lifecycle-based process model for simulating environmental performance, product performance and cost in cement manufacturing. J. Clean. Prod. 2004, 12, 77-93. [CrossRef]

122. Stafford, F.N.; Raupp-Pereira, F.; Labrincha, J.A.; Hotza, D. Life cycle assessment of the production of cement: A Brazilian case study. J. Clean. Prod. 2016, 137, 1293-1299. [CrossRef]

123. Van Den Heede, P.; De Belie, N. Environmental impact and life cycle assessment (LCA) of traditional and "green" concretes: Literature review and theoretical calculations. Cem. Concr. Compos. 2012, 34, 431-442. [CrossRef]

124. Galvez-Martos, J.L.; Schoenberger, H. An analysis of the use of life cycle assessment for waste co-incineration in cement kilns. Resour. Conserv. Recycl. 2014, 86, 118-131. [CrossRef]

125. Georgiopoulou, M.; Lyberatos, G. Life cycle assessment of the use of alternative fuels in cement kilns: A case study. J. Environ. Manag. 2018, 216, 224-234. [CrossRef] [PubMed]

126. Italcementi Group. Environmental Product Declaration as per ISO 14025 and EN 15804; Institut Bauen und Umwelt e.V. (IBU): Berlin, Germany, 2012; Available online: https: / / epd-online.com/EmbeddedEpdList/ Download/9128 (accessed on 22 December 2018).

(C) 2019 by the authors. Licensee MDPI, Basel, Switzerland. This article is an open access article distributed under the terms and conditions of the Creative Commons Attribution (CC BY) license (http:// creativecommons.org/licenses/by/4.0/). 